\title{
The Role of Supervisory Tools in Addressing Bank Borrowers' Currency Mismatches
}

Maria del Mar Cacha and

R. Armando Morales 


\title{
IMF Working Paper
}

Monetary and Financial Systems Department

\section{The Role of Supervisory Tools in Addressing Bank Borrowers' Currency Mismatches}

\author{
Prepared by Maria del Mar Cacha and R. Armando Morales ${ }^{1}$ \\ Authorized for distribution by David Marston and Patricia Brenner
}

November 2003

\begin{abstract}
The views expressed in this Working Paper are those of the author(s) and do not necessarily represent those of the IMF or IMF policy. Working Papers describe research in progress by the author(s) and are published to elicit comments and to further debate.
\end{abstract}

Bank borrowers' currency mismatches often result from unhedged foreign currency borrowing in economies where there is significant dollarization, exposing the financial sector to disguised credit risk. In the absence of standard tools or guidelines to counteract this risk, countries have resorted to outright regulatory limits in cases of moderate dollarization and to undesirable exchange controls in other cases. This paper proposes a "specific-to-group" provision rule based on the effective borrowing cost differential between domestic and foreign currency. Such a rule would help internalize the corresponding risks for banks and their borrowers in line with internationally accepted prudential and accounting standards.

JEL Classification Numbers: G21, G28.

Keywords: Prudential regulation, currency mismatches, provisions

Authors’ E-Mail Address: maicacha@core.com; amorales@imf.org

\footnotetext{
${ }^{1}$ Banks of Spain and IMF-MFD respectively. Special thanks are extended to David Marston for suggestions provided during the preparation of a Monetary and Financial Systems Department's (MFD's) paper on financial stability in dollarized economies. We are also thankful for comments from participants in an MFD seminar, especially Patricia Brenner, Luis Cortavarria, Eva Gutierrez, Paul Kupiec and Gabriel Sensebrenner. Jia Liu and Steen Biskov provided valuable research assistance.
} 
I. Introduction 3

II. The Nature of Exchange-Rate-Induced Credit Risk in Partially Dollarized Economies 4

III. Country Practices in Exchange-Rate-Induced Credit Risk Management and Some Alternatives .

A. Country Practices to Address Unhedged Foreign Currency Lending .......................8

B. Some Alternative Proposals to Address Unhedged Foreign Currency Lending......10

IV. Impact of Provisioning Based on Borrowing Cost Differentials

A. Expected and Actual Exchange Rate Depreciation.......................................... 16

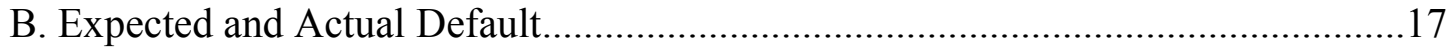

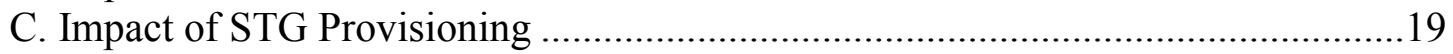

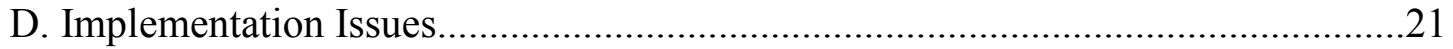

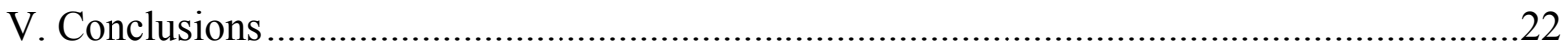

Figures

1. Real Effective Cost of Credit for Selected Countries, 1992-2000 ..................................6

2. Country Risk and Credit Risk Premia in Foreign Currency Intermediation in Selected Dollarized Economies, 1991-2000

Boxes

1. Motivations for Private Sector Unhedged Borrowing ...............................................5

2. Motivations for Public Sector Unhedged Borrowing ............................................... 8

Appendix

Country Practices to Address Exchange-Rate-Induced Credit Risk

References 


\section{INTRODUCTION}

In general, rapid development of dollar-denominated operations in the banking system increases the risk of crises in financial and foreign exchange markets (Baliño, Bennett and Borensztein, 1999). At the same time, increased globalization of financial markets and liberalization of domestic financial systems can lead to an increase in dollarization, including of loans, within a short period of time in emerging market economies (Barajas and Morales, 2003). The level of dollarization of the real economy may differ from dollarization in the financial system, creating potential mismatches of assets and liabilities in the corporate and public sectors. Thus, partially dollarized economies present particular sources of risks related to currency mismatches, which entail risks and corresponding management costs. If risks are not adequately assessed, and the costs not internalized, this process may magnify the adverse impact of eventual inconsistencies between interest rate differentials and exchange rate expectations for prolonged periods. Potential losses for the banking system of an uncertain magnitude would result from "balance sheet effects" in the event of sudden episodes of exchange rate depreciation. If these effects were accompanied by maturity mismatches, they would also increase banks' vulnerability to volatile capital flows.

This paper deals with the currency mismatch between the currency of denomination of loans and that of borrowers' cash flows, along with possible prudential responses to addressing the mismatch. Adequate identification of the risks involved would facilitate an appropriate assessment of the tools best suited to mitigate them, with special care taken to avoid arresting financial development, since dollarization is often part of a larger process of financial market integration. However, the choice of the most appropriate instruments to counteract undue credit risk exposure by banks and/or bank customers is made more difficult by the absence of agreed-upon adaptations of prudential rules and references from industrial-country bank regulations. ${ }^{2}$ As a result, the selection of tools must be complemented by flexibility in their use by supervisory authorities, including adapting the corresponding regulatory framework.

The paper is organized as follows: Section II deals with the nature of exchange-rate-induced credit risk and the different motivations of banks, borrowers and authorities. Section III discusses country practices to address this risk, based on information available in the IMF Annual Report on Exchange Arrangements and Exchange Restrictions. Section IV discusses some proposals, in particular the introduction of a provision rule based on the effective borrowing cost differential between domestic and foreign currencies. The rule is assessed for its consistency with the latest discussions on improving the supervisory framework in relevant institutions and/or forums (Basel Committee, Financial Stability Forum, IASCF). Section V summarizes and concludes.

\footnotetext{
${ }^{2}$ For industrial countries, this issue has not been a matter of concern. See Delgado and others (2002).
} 


\section{The Nature of Exchange-Rate-Induced Credit Risk in Partially DOLLARIZED ECONOMIES}

Lenders in dollarized countries face unique credit risks that to some extent result from deliberate actions by banks to help contain foreign currency mismatches. To the extent that banks intermediate sizable dollar liabilities, they would acquire dollar-denominated assets through granting foreign currency loans to domestic clients, even though some borrowers' cash flow may be denominated in domestic currency. While effectively transferring the foreign exchange risk to the borrower, banks retain the credit risk resulting from the possibility that the borrower's currency mismatch affects its capacity to repay the loan in the face of adverse exchange rate fluctuations. Counterparty exposure is also amplified if the value of the collateral backing the loan obligation - denominated in domestic currencydeclines consequent on the exchange rate movement.

Notwithstanding these risks, both borrowers and lenders operate in a unique incentive framework. Borrowers operating in the context of fixed exchange rate or "fear of floating" regimes expect that the exchange rate risk will not materialize within the maturity of their loans, since bank lending is generally short-term and spreads are generally lower for intermediation in foreign currency relative to domestic currency. Figure 1 shows that there may be grounds to justify this behavior, as the costs of borrowing in foreign currency (incorporating exchange rate depreciation) are generally significantly lower in dollarized economies relative to domestic currency. This is not observed in a non-dollarized economy such as Chile. Consistent with this, in dollarized economies borrowers perceive that costs entailed in holding a currency mismatch in their balance sheets are lower in "normal" times than those of borrowing in a weak domestic currency (for which interest rates show higher spreads and volatility).

In addition to these relative cost considerations, structural factors, including the limited availability of hedging instruments in many emerging markets and the shallowness of domestic credit markets may also motivate unhedged foreign currency lending (Box 1). Moreover, relative cost considerations are often accompanied by moral hazard and structural issues. Borrowers believe that monetary authorities would continue to honor commitments to the exchange rate regime even in adverse circumstances, preferring low variability of nominal exchange rates to high interest rate volatility, or alternatively bailing out distressed firms. In any event, borrowers benefit from this perceived exchange rate insurance as governments try to hold reserve assets while at the same time insuring the financial liabilities of residents. Governments, in turn, may have conflicting interests, for example, if a large share of public debt is denominated in foreign currency, especially if it is held by domestic commercial banks (Box 2).

Banks lend in foreign currency as the highest-yield alternative to allocate liabilities while keeping their foreign exchange position balanced. Safer alternatives may offer yields that are not sufficient to compensate for the country risk premium incorporated into foreign currency deposit interest rates. Figure 2 shows for a sample of countries that domestic banks are able to charge borrowers in foreign currency an interest rate above the U.S. prime rate relatively proportional to the country risk premium (the difference between the domestic 3-month 
deposit rate in foreign currency and the 3-month U.S. Treasury bill rate). It may also be the case that dollarization alters the comparative advantage of domestic banks vis-à-vis foreign banks. Foreign banks often compete domestically by channeling resources mobilized at a cost closer to the risk-free rate of their home countries to domestic borrowers. Thus, to retain market share and prime customers, domestic banks may be increasingly forced to relax hedging requirements.

\section{Box 1. Motivations for Private Sector Unhedged Borrowing}

Motivations other than costs to embark on unhedged borrowing include the following:

\section{Swaps}

Borrowers may temporarily hold unhedged liabilities in foreign currency to wait for opportunities to swap. However, this may not be significant in emerging economies' financial markets.

\section{Foreign currency borrowing motivated by time-structure incentives}

Exchange rate depreciation directly affects the nominal domestic value of the loan principal. Therefore, the domestic currency value of repayments increases throughout the repayment period in the event of continuous depreciation. For loans in foreign and domestic currency in equivalent terms, matching exchange rate depreciation and lending interest rate hikes would result in a more acute skewness of the repayment schedule for foreign currency loans, which for some activities of slow maturity could be convenient.

\section{Foreign currency borrowing to import productive assets}

Some borrowers pay for imported equipment in foreign currency and borrow in foreign currency to avoid differences between contracting and settlement values. Often the loan is not refinanced in domestic currency to keep the foreign exchange obligation related to the valuation of the corresponding asset that normally serves as collateral, some times even if the corresponding asset is not marketable abroad.

\section{Foreign currency borrowing by import-substitution activities}

Economic activities benefiting from an exchange rate depreciation also include those that benefit from a recomposition of demand against competing imports. Domestic providers of tradable goods and services to the domestic market are then indirectly hedged by borrowing in foreign currency, as exchange rate depreciation allows them to capture additional domestic demand.

\section{Foreign currency borrowing by commodity-related activities}

In countries that are highly dependent on exports of internationally traded commodities, commodity producers would normally require foreign currency financing. Moreover, the cash flow of companies that provide inputs and services to commodity producers will be linked indirectly to international prices and exchange rate depreciation. Thus, they may seek foreign currency financing in order to minimize their cash flow volatility.

\section{Foreign currency borrowing by agents operating domestically}

In principle, residents who receive a foreign currency cash flow in dollarized economies are naturally hedged if there is full pass-through from exchange rate changes to inflation within a short time period. In this event, local borrowers may be able to assume the exchange rate risk of a foreign-currency-denominated loan even if they have no foreign currency receivables. The pass-through coefficient has been found to be higher in emerging markets than in developed economies (Calvo and Reinhart, 2000; and Honohan and Shi, 2002) Also, greater dollarization is generally associated with a higher pass-through. 
Figure 1. Real Effective Cost of Credit for Selected Countries, 1992-2000

Bolivia

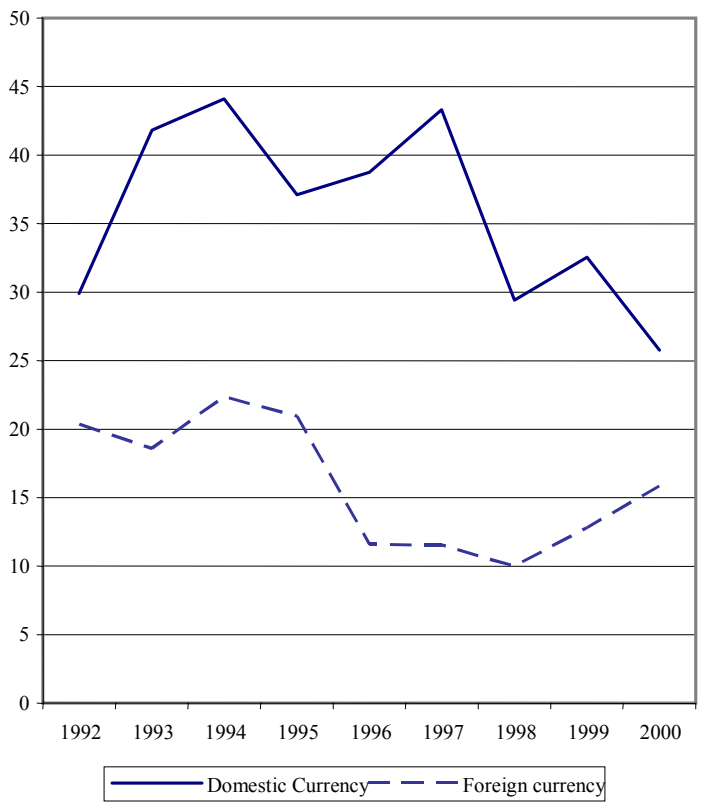

Uruguay

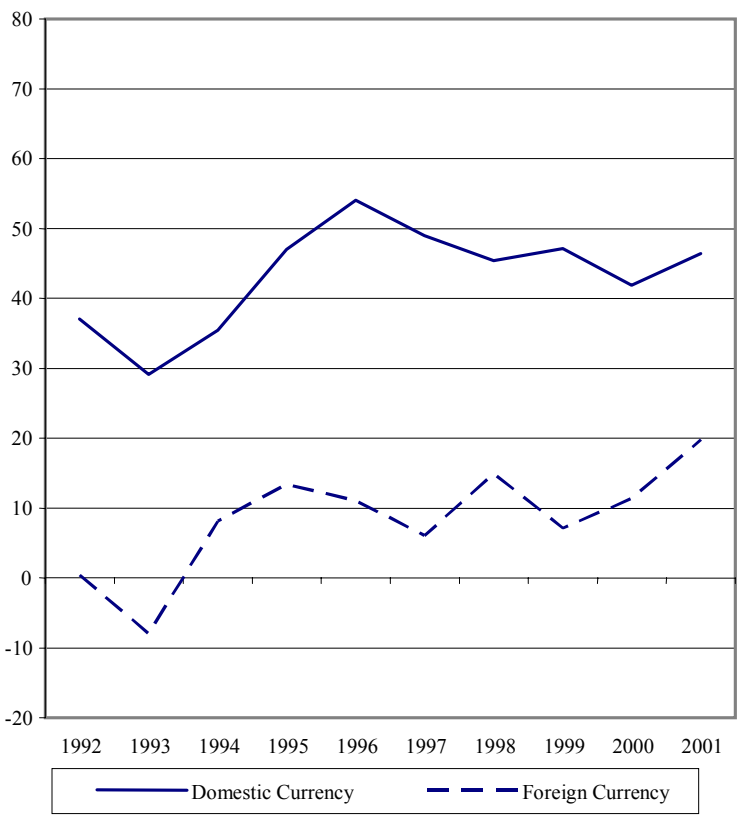

Paraguay

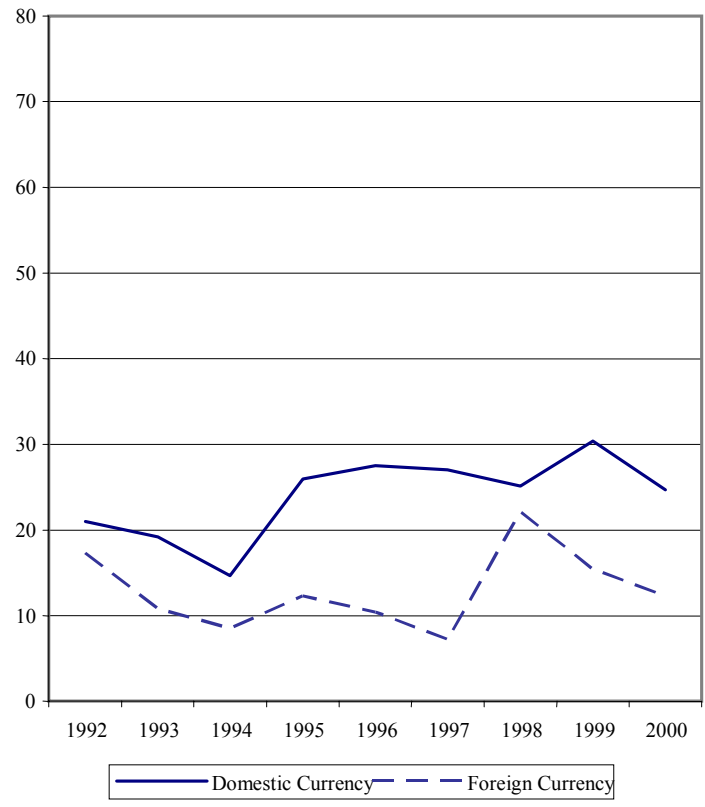

Chile

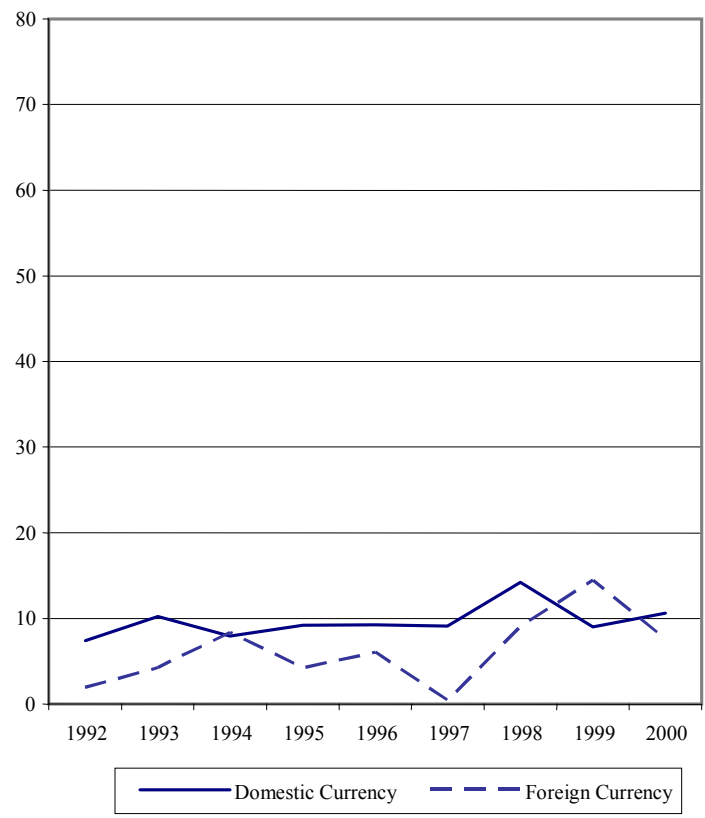

Source: Country data and staff calculations.

Annualized real interest rates calculated based on consumer price indices for domestic currency lending and on the real effective exchange rate for foreign currency lending. 
Figure 2. Country Risk and Credit Risk Premia in Foreign Currency Intermediation in Selected Dollarized Economies, 1991-2000

Argentina

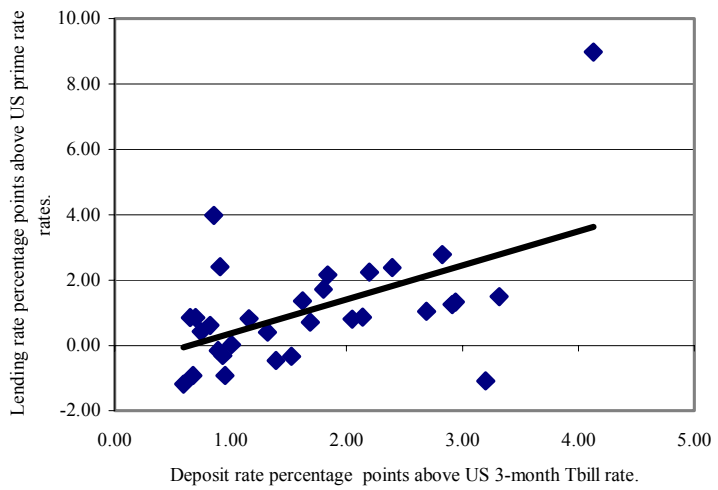

Bolivia

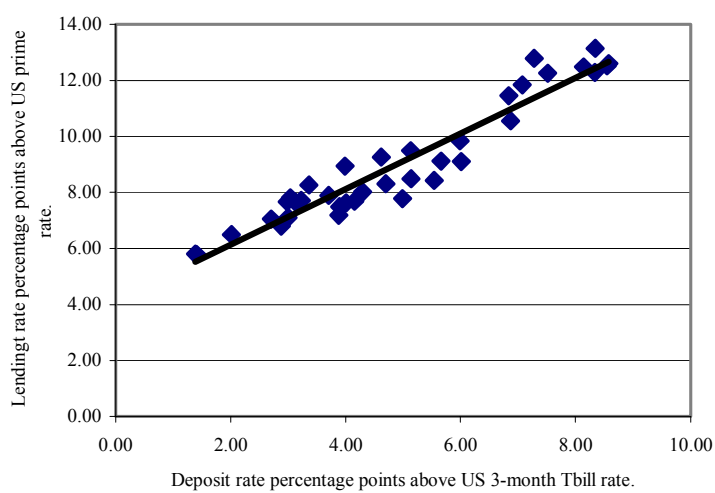

Georgia

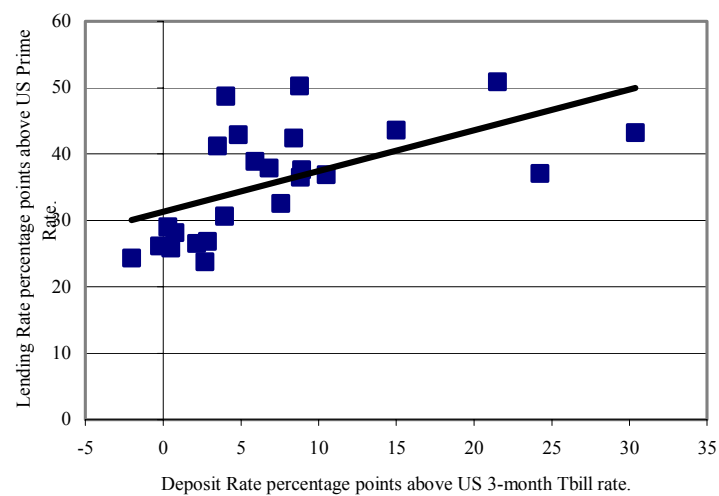

Peru

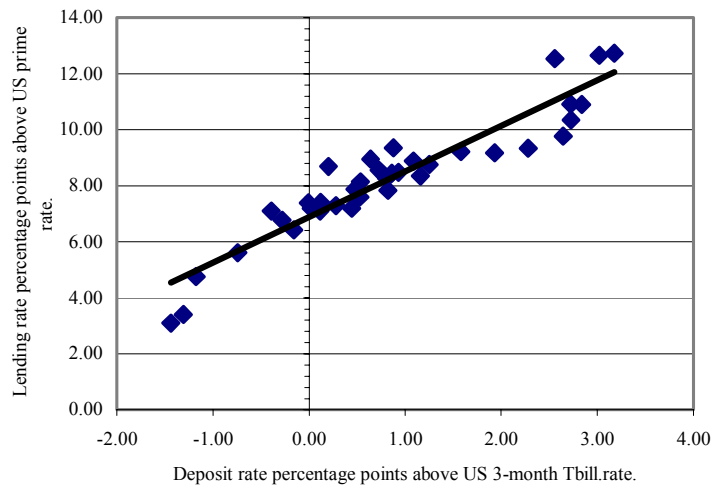

Paraguay

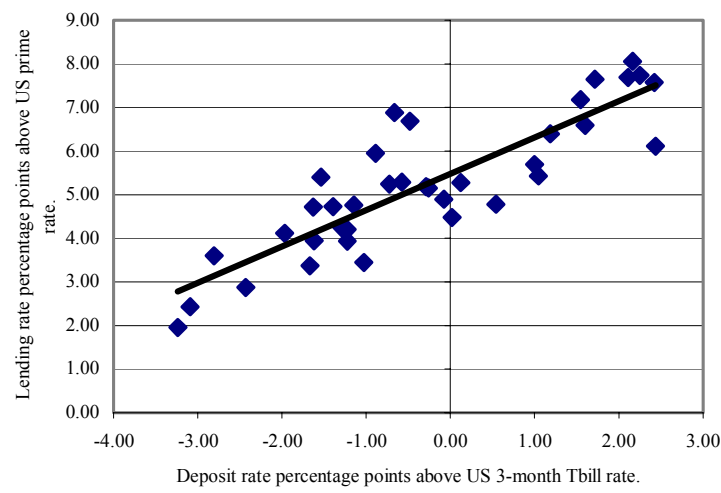

Uruguay

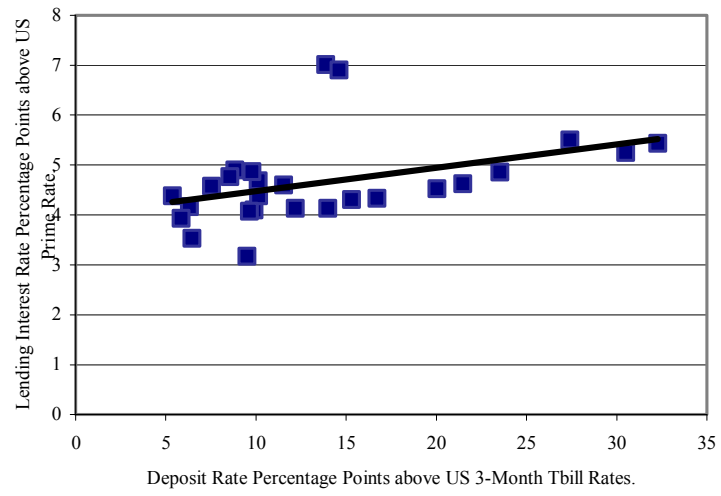

Source: Bloomberg, country data, and staff calculations. 
Box 2. Motivations for Public Sector Unhedged Borrowing

Government borrowing in dollarized economies responds to different motivations. First, like corporate borrowers, the government perceives that foreign currency loans provide a less costly source of financing, which encourage unhedged borrowing since the sources of government revenue are mainly denominated in domestic currency. Second, by borrowing in foreign currency, the government resorts to domestic and foreign sources of financing, which facilitates full satisfaction of financing needs. Third, related to the previous point, government borrowing from abroad does not have an immediate "crowding out" impact against the private sector, unlike borrowing domestically in domestic currency, which could lead to higher domestic interest rates, complicating overall macroeconomic policy management.

However, there are also disadvantages for the economy as a whole if the government increases the share of foreign currency financing in their total liabilities. First, by increasing exchange rate risk, it makes debt sustainability highly dependent on the evolution of the exchange rate (illustrated recently by Brazil). Second, as government borrowing is the benchmark for the risk-free interest rate in foreign markets, it may lead to an increase of country risk that will affect the cost of foreign financing for other economic agents. Third, by providing assets to commercial banks in dollarized economies, it increases the costs of default for the economy by creating systemic risk. Fourth, it aggravates liquidity crises in the event of currency turmoil as the risk of government default leads to contractual default by corporate borrowers (whose debt-to-earnings ratio moves above agreed limits, which usually gives creditors the right to demand early repayment).

Governments have conflicting interests when a large segment of public debt is denominated in foreign currency, especially if it is held by domestic commercial banks. If the central bank is not fully independent, government may press to keep the exchange rate stable to minimize the cost of public debt. This in turn feeds into the expectations of banks and borrowers, since the event of default would be associated with such a deterioration in the macroeconomic environment that the central bank and the government would not be expected to "let it happen." Moreover, banks may be attracted to hold government securities regardless of the quality of debt management to the extent that they are not subject to capital requirement.

Government debt management strategies rarely strike a balance between expected costs and risks, from a longterm perspective. This is especially important in a pegged exchange rate regime, where actual costs in foreign currency do not increase until a major crisis erupts. The magnitude of contingent liabilities remains unknown since the government does not have an interest in making them explicitly and as government obligations are not subject to market valuation in many cases.

\section{Country Practices in Exchange-Rate-Induced Credit Risk Management AND SOME Alternatives}

\section{A. Country Practices to Address Unhedged Foreign Currency Lending}

The Basel Committee on Banking Supervision (BCBS) has issued several guidelines for adequate banking supervision, and specific documents on the management and supervision of the main risks of banks (BCBS, 1997). However, the choice of the most appropriate instruments to counteract risk exposure by banks and/or bank's customers in dollarized economies has been made difficult because there have been no agreed-upon specific adaptations to prudential regulations to date. Moreover, this issue has not been a matter of concern for industrial economies, normally operating in a hard currency environment where their domestic currency is accepted internationally (Delgado and others, 2002). 
Generally, the discussion about the use of prudential regulations to prevent unhedged foreign currency lending to residents is still in the initial stages. In the absence of references for prudential regulations, a minority of countries resort to some type of exchange controls, although several countries have been phasing out restrictions in recent years. ${ }^{3}$ In the IMF's 2002 Annual Report on Exchange Arrangements and Exchange Restrictions (AREAER), 41 out of 167 countries report some kind of restriction related to exchange-rate-induced credit risk (see Appendix). ${ }^{4}$ The main features observed in the measures undertaken by these countries are the following:

- $\quad$ Countries that do not restrict these operations include basically all developed economies, and most highly dollarized economies: Only two out of the 10 most dollarized economies show some kind of restriction (Angola and Croatia). ${ }^{5}$

- $\quad$ Outright prohibition is a rare practice, adopted by only three countries (Dominica, Macedonia, and Namibia). ${ }^{6}$ Seven countries impose a quantitative limit (Bangladesh, Haiti, Honduras, Jordan, Malaysia, Mexico, and Thailand). Average deposit dollarization is 14 percent of total deposits for this group of countries, a relatively moderate ratio.

\footnotetext{
${ }^{3}$ Notably Chile and Mexico.
}

${ }^{4}$ A parallel survey on supervisory practices resulted in all countries reporting that no specific prudential measures were in place. The following countries and areas do not report any restrictions to the AREAER: Albania, Argentina, Armenia, Aruba, Australia, Austria, Azerbaijan, Bahrain, Barbados, Belgium, Belize, Bhutan, Bolivia, Bosnia, Botswana, Brunei, Bulgaria, Burundi, Cambodia, Cameroon, Canada, Cape Verde, Chad, Chile, Colombia, Comoros, Czech Republic, Democratic Republic of Congo, Denmark, Djibouti, Ecuador, Egypt, El Salvador, Equatorial Guinea, Eritrea, Estonia, Ethiopia, Finland, France, The Gambia, Georgia, Germany, Ghana, Greece, Grenada, Guatemala, Guinea, Guinea-Bissau, Guyana, Hong Kong SAR, Hungary, Iceland, India, Indonesia, Islamic Republic of Iran, Iraq, Ireland, Israel, Italy, Jamaica, Japan, Kenya, Korea, Kuwait, Kyrgyz Republic, Lao PDR, Latvia, Lebanon, Lesotho, Liberia, Lithuania, Luxembourg, Malawi, Maldives, Malta, Mauritania, Mauritius, Morocco, Mongolia, Mozambique, Netherlands, Netherlands Antilles, New Zealand, Nicaragua, Nigeria, Norway, Oman, Pakistan, Palau, Panama, Paraguay, Peru, Poland, Portugal, Qatar, Romania, Russia, Rwanda, Saint Lucia, Samoa, San Marino, Solomon Islands, Säo Tomé and Príncipe, Saudi Arabia, Seychelles, Slovenia, South Africa, Spain, Sudan, Swaziland, Sweden, Switzerland, Tajikistan, Tanzania, Tonga, Trinidad and Tobago, Turkmenistan, Uganda, United Arab Emirates, United Kingdom, United States, Uruguay, Uzbekistan, Venezuela, Republic of Yemen, and Zambia.

${ }^{5}$ Based on the most recent available information, the other eight countries are Armenia, Azerbaijan, Bolivia, Cambodia, Democratic Republic of Congo, Georgia, Peru, and Uruguay.

${ }^{6}$ Circumventing this prohibition using legal loopholes is not infrequent. 
- $\quad$ Countries tend to restrict the application of funds rather than their origin. Only three countries limit these operations based on their source of funding (Algeria, Brazil, and Moldova). Between 12 and 16 countries have either an administrative restriction (official approval) and/or a restriction on the type of lenders and/or borrowers that could resort to this type of intermediation; or on the use of funds. Average deposit dollarization is 33-35 percent of total deposits for this group of countries.

- $\quad$ Countries requiring official approval may have other motivations than restricting unhedged foreign currency lending. Five countries belong to the Banque Centrale des Etats de l'Afrique de l'Ouest (BCEAO). Four other countries conduct sizable offshore activities and use this mechanism as a record-keeping device (Bahamas, Fiji, Papua New Guinea, St. Kitts and Nevis). Other countries have other exchange controls in place (China and Malaysia). This leaves no more than eight countries that may have resorted to this mechanism mainly to restrict unhedged lending.

In general, restrictions on unhedged foreign currency lending are basically exchange controls. While quantitative limits may work for moderate dollarization levels, favored restrictions are on the use of funds, the borrowers and/or the lenders. By contrast, dollarized economies in the sample do not report limitations probably because the high share of foreign currency deposits would make any restriction difficult to implement.

\section{B. Some Alternative Proposals to Address Unhedged Foreign Currency Lending}

The risk management spectrum of country practices concerning exchange-rate-induced credit risk spans the incomplete incorporation of exchange risk into credit pricing at one end and the prohibition of foreign currency lending and mandatory narrow intermediation at the other end. Main measures to be considered are the following:

- In principle, requiring that banks lend in foreign currency only to hedged borrowers (naturally hedged by foreign currency cash flow or financially hedged by using appropriate financial instruments) seems appropriate, but could be impractical for several reasons. First, for highly dollarized countries, there are not many other profitable alternatives to allocate foreign currency deposits. Second, if prime borrowers have direct access to foreign borrowing, by losing prime customers domestic banks may lose a source of associated revenue and experience a deterioration of the quality of their portfolio in favor of foreign banks. Third, customarily distorted interest rates may lead to excessive hedging costs that do not reflect exchange rate expectations effectively in the economy. ${ }^{7}$ Therefore, limiting foreign currency lending to hedged borrowers may be advocated in countries with low initial dollarization, a solid banking system, and well-functioning financial markets. Even in this case, the extent of credit demand being shifted abroad and the

\footnotetext{
${ }^{7}$ Anecdotal evidence shows that foreign banks do not hedge when the costs of hedging are perceived as distorted. So imposing hedging would be forcing banks to adopt practices not used by their competitors.
} 
eventual impact of this on the domestic financial system should be continuously monitored.

- $\quad$ Limiting foreign currency loans to an arbitrary maximum, for example a fixed percentage of capital, or in line with measures toward limiting part of foreign exchange intermediation to narrow banking, runs the risk of encouraging misreporting in order to avoid such limitations. In any event, it does not ensure that those borrowers who manage to have access to foreign currency loans in the new framework are necessarily the ones bearing lower credit risk, and consequently, it may unduly limit the availability of credit to those who properly manage the entailed foreign currency risks. However, a limit could be set for individual cases, for example if a few rogue banks are exposed to foreign currency loans far above the system's average, with foreign currency loans granted with less strict criteria in order to attract customers at the cost of additional disguised credit risk.

- $\quad$ Another standard tool that could compensate for this risk would be requesting extra collateral coverage to incorporate exchange-rate-induced credit risk. However, problems of collateral valuation in emerging market economies constitute a limitation, compounded by the asset price volatility in developing financial markets, with asset price declines often coincidental with periods of accelerated exchange rate depreciation.

Making foreign currency lending more costly for banks and borrowers using prudential tools is an alternative to a large extent not yet tested in the market. Provisions seem preferable to capital requirements for this purpose, since they allow for a prompter recognition of identifiable problems. ${ }^{8}$ The incorporation of exchange risk into credit pricing would be made possible if banks include among the criteria for loan classification purposes exposure to unhedged exchange rate risk. However, anecdotal evidence suggests that this practice is only followed by conservative institutions, and it could only be generalized through supervisory monitoring.

Sufficient theoretical support justifies provisions specific to a group of borrowers (in this case unhedged borrowers in foreign currency), based on the fact that unhedged foreign currency lending for highly dollarized countries is an attribute relevant to the assessment of the banks' ability to collect the loans. Current proposals to improve International Accounting Standard 39 include guidelines on how to evaluate "impairment that is inherent in a group of loans (or receivables) that cannot yet be identified with an individual financial asset." (International Accounting Standards Committee Foundation, 2002a). One of the criteria is to group assets by "similar credit risk characteristics indicative of the debtors' ability to pay all amounts due according to contractual terms." Likewise, the current proposed guidance on loan classification and provisioning by the Accounting Task Force of the Basel Committee, recommends that the assessment of loans should reflect all relevant loss attributes that affect

\footnotetext{
${ }^{8}$ This section does not deal with the treatment of recommended provisions in the determination of capital requirements.
} 
the collectability of the loan, including "the nature and degree of protection provided by the current and stabilized cash flow."

In this vein, specific-to-group (STG) provisions on unhedged foreign currency assets held to maturity could be justified. The criterion to measure potential impairment must be objective, and at the same time, it should not put supervisory authorities in the position of establishing "official" expectations on interest rates and/or exchange rate changes. One practical approach for those banks that may not be in the position to adopt advanced techniques would be to establish loan-loss provisions proportional to the historical difference between the banks' domestic and foreign currency lending rates (net of exchange rate depreciation). ${ }^{9}$ This would have the following advantages:

- $\quad$ It would make foreign currency lending more costly to banks in proportion to their individual exposure to unhedged borrowing.

- If provisions are established based on the individual bank's lending rates, they would entail a higher provision on banks that make domestic currency loans unduly expensive to encourage use of foreign currency loanable funds.

- $\quad$ This provision would correct ex-ante long foreign exchange positions to account for embedded credit risk. If banks still want to keep foreign exchange positions at the level prior to the eventual imposition of the provisions, they must increase their investment in other foreign currency assets.

- $\quad$ This would also be consistent with Basel recommendations to quantify the expected loss using historical experienced-based loss rate models adjusted to reflect current conditions. In this case, it would be the "expected" loss resulting from delays in adjustments toward the uncovered interest parity condition for loans in different currencies.

A more stringent measure would be the requirement to establish an external fund equivalent to the amount being provisioned, to cover for the eventuality of default following an abrupt exchange rate depreciation. Alternatively, banks could charge their customers explicitly (rather than through higher interest rates), turning the mechanism into credit insurance to be triggered in the event of exchange rate-induced loan defaults. To ensure more transparency, this credit insurance could be provided by insurance companies unrelated to the bank granting the loan. In both cases, a cost-benefit analysis by the supervisory authority would incorporate an assessment of the impact on profit-loss statements.

Complementary measures may include:

${ }^{9}$ Accounting for differentials explained by microeconomic factors, such as differential taxation on interest and reserve requirements, among others. 
- The promotion by the government of hedging mechanisms such as devising schemes to facilitate the use of pension funds (which in dollarized economies normally hold foreign currency assets and domestic currency liabilities) to provide credit risk protection under certain conditions.

- $\quad$ The public announcement of effective lending interest rates by banks (in their advertising campaigns and as part of the contract contents), including the conversion of foreign currency lending rates to the domestic equivalent based on the previous year's lending interest rate differential. This would help borrowers internalize the real lending costs entailed in their borrowing (especially households).

- $\quad$ Mandatory disclosure by banks of the extent of unhedged lending (at the minimum to supervisory authorities initially, with a view to disclosing it to the public at a later stage). Also, corporate sector currency mismatches could be monitored by credit registries when they are available, explicitly relating credit rating to currency risk.

\section{Impact of Provisioning Based on Borrowing Cost Differentials}

In this section, the impact of the proposed STG provisioning is assessed based on the borrowing cost differential between domestic and foreign currency in a standard bank accounting framework and some additional assumptions, to identify the relevant costs and yields affected by this measure. First, a basic scenario is set up in the format of a bank's balance sheet identifying the relevant yields on bank assets and liabilities. For a bank with zero equity and whose only liabilities are foreign currency deposits $(D x)$, domestic currency deposits $(D d)$, and foreign borrowing $(G x)$ :

$$
\text { Total liabilities }=D x+D d+G x \text {. }
$$

There are three kinds of risk: default risk $(\sigma f)$, country risk $(\sigma p)$ and currency risk $(\sigma c)$ :

- Default risk is the risk of not being repaid, assumed to be the same for lending to domestic financial and nonfinancial agents.

- $\quad$ Country risk is the risk of depositors not being able to withdraw their deposits for systemic reasons.

- $\quad$ Currency risk is the risk of exchange rate losses.

There is a "safe haven" risk-free interest rate $(r x)$ which is what a domestic agent (financial or nonfinancial) would receive as remuneration for foreign currency deposits abroad. Domestic banks get zero profits for intermediating deposits. Foreign banks as a whole also obtain zero profits if deposits from domestic banks are equal in magnitude to their lending to domestic banks. The corresponding interest rates paid by the bank on its liabilities are in period zero: 
In foreign currency:

$$
\begin{array}{lll}
D x & : & r_{0} d_{x}=r_{0} x+\sigma_{0} p \text { and } \\
G x & : & r_{0} g_{x}=r_{0} x+\sigma_{0} f .
\end{array}
$$

In domestic currency:

$$
\text { Dd : } \quad r_{0} d_{d}=r_{0} x+\sigma_{0} p+\sigma_{0} c .
$$

This interest rate schedule is consistent with the following simplifying assumptions:

- $\quad$ Foreign currency deposits would shift to the safe haven location if $r d_{x}-r x<\sigma p$.

- Depositors in domestic currency are compensated for currency risk in addition to country risk $\left(r d_{d}>r d_{x}\right.$ if currency depreciation is expected).

- $\quad$ Foreign lenders operate with domestic banks as long as they are "immune" to the country risk premium, and would leave otherwise.

The bank holds the following assets: Foreign currency loans $(C x)$, domestic currency loans $(C d)$, and foreign securities $(S x)$, such that:

$$
\begin{aligned}
& \text { Total assets }=C x+C d+S x, \text { and } \\
& \text { Total assets }=\text { Total liabilities } .
\end{aligned}
$$

The corresponding interest rates charged by the bank on its assets are:

In foreign currency:

$$
\begin{array}{ll}
C x \quad: & r_{0} c_{x}=r_{0} x+\sigma_{0} p+\sigma_{0} f, \text { and } \\
S x \quad: & r_{0} s_{x}=r_{0} x .
\end{array}
$$

In domestic currency:

$$
C d \quad: \quad r_{0} c_{d}=r_{0} x+\sigma_{0} p+\sigma_{0} c+\sigma_{0} f .
$$

This interest rate schedule is consistent with the following simplifying assumptions:

- The margins on loans over deposits only compensates for the ex-ante default risk (consistent with the assumption of zero profits).

- Domestic banks make an "extra-profit" given by intermediating foreign loans, as they charge the country premium that is not repaid in turn to foreign lenders. 
- $\quad$ By contrast, foreign securities only pay the safe haven risk-free interest rate $r x$ for bank deposits abroad. ${ }^{10}$

The ex-post interest rate schedule expressed in domestic currency (in period 1) would be affected by the actual exchange rate depreciation $(\delta)$ for intermediation in foreign currency and by the default on loans in both currencies $(\Theta)$. A one-period lag is assumed between actual exchange rate depreciation and default and the corresponding currency and default risk components of interest rates where: ${ }^{11}$

$$
\begin{aligned}
& D x \quad: \quad r_{1} d_{x}=\left(1+r_{1} x+\sigma_{1} p\right)\left(1+\delta_{1}\right)-1 \\
& \text { Dd } \quad: \quad r_{1} d_{d}=r_{1} x+\sigma_{1} p+\sigma_{0} c \\
& C x: \quad r_{1} c_{x}=\left\{\left(1+r_{1} x+\sigma_{1} p+\sigma_{0} f\right)\left(1+\delta_{1}\right)-1\right\}\left(1-\Theta_{1}\right) \\
& C d \quad: \quad r_{1} c_{d}=\left(r_{1} x+\sigma_{1} p+\sigma_{0} c+\sigma_{0} f\right)\left(1-\Theta_{1}\right) \\
& S x \quad: \quad r s_{x}=\left(1+r_{1} x\right)\left(1+\delta_{1}\right)-1 \\
& G x: r_{1} g_{x}=\left\{\left(1+r_{1} x+\sigma_{0} f\right)\left(1+\delta_{1}\right)-1\right\}\left(1-\Theta_{1}\right) \text {. }
\end{aligned}
$$

Making total assets and liabilities equal to one for simplification purposes:

$$
D x+D d+G x=C x+C d+S x=1 \text {. }
$$

Adding the assumption that the bank aims at eliminating currency risk by keeping its foreign exchange position balanced:

$$
D x+G x=C x+S x .
$$

The risk free alternative would always have a remuneration lower than the cost of resources (deposits or loans) if country risk premium is positive. Therefore, the combination of a balanced foreign exchange position and low yield in safe securities would tend to induce banks to increase Cx up to the availability of foreign currency loanable resources, before taking risk into consideration, such that:

$$
C x=D x+G x
$$

\footnotetext{
${ }^{10}$ In other words, the foreign bank does not charge for the country premium, but it also does not compensate for that when receiving deposits.

${ }^{11}$ For example, because of central bank intervention in the foreign exchange market and inadequate balance sheet information about delays in repayment.
} 
Let us introduce the role of exchange rate expectations to further analyze the incentive structure.

\section{A. Expected and Actual Exchange Rate Depreciation}

Assuming an initial endowment of total deposits $(\check{D})$ and an initial maximum bank's borrowing capacity from abroad $(\breve{G} x)$ :

$$
\begin{aligned}
& D x+D d=\check{D}, \text { and } \\
& G x=\breve{G} x .
\end{aligned}
$$

In perfect foresight, we have:

$$
\begin{aligned}
& \mathrm{E}\left(\delta_{1}\right)=\delta_{1} \text { and } \\
& \delta_{1}=\sigma_{0} c /\left(1+r_{1} x+\sigma_{1} p\right) .
\end{aligned}
$$

Equation (7) ensures that the currency risk component in domestic interest rates reflects perfect foresight in exchange rate expectations. ${ }^{12}$

In addition to the lag in expectations, it is assumed that borrowers only worry about the period of maturity of their loans to decide on the currency of denomination of their loans. By contrast, banks and depositors make decisions on their holdings considering more than one period. This could be represented by incorporating transaction costs $(\varsigma)$ affecting the decision to change the banks' foreign exchange position and the currency composition of deposits. These transaction costs do not affect decisions on the currency denomination of loans (for which the flows in every period equal the stock), since borrowers must modify their decisions in each period anyway when contracting a new loan:

$$
\begin{array}{rr}
\Delta\{(C x+S x) /(D x+G x)\}=f\left\{\left(\delta_{1}-\sigma_{0} c /\left(1+r_{1} x+\sigma_{l} p\right)\right\}\right. & \text { if } \mathrm{ABS}\left(\delta_{1}-\sigma_{0} c /\left(1+r_{l} x+\right.\right. \\
\left.\left.\sigma_{l} p\right)\right\}>\varsigma \text {, and zero otherwise. } & +
\end{array}
$$

$$
\begin{gathered}
\Delta(D x / \check{D})=g\left\{\delta_{1}-\sigma_{0} c /\left(1+r_{1} x+\sigma_{1} p\right)\right\} \text { if } \mathrm{ABS}\left(\delta-\sigma_{0} c /\left(1+r_{1} x+\sigma_{1} p\right)\right\}>\varsigma \text {, and zero } \\
\text { otherwise. }
\end{gathered}
$$

Abandoning the perfect foresight assumption, as the borrower contracts a loan in period zero, the repayments will include the prevailing $\sigma_{0} c$ in domestic currency. Therefore, for a given demand for credit $\breve{C}$ :

$$
\check{C}=\breve{G} x+D x+C d \quad \text { if } \delta_{1}<\sigma_{0} c /\left(1+r_{1} x+\sigma_{l} p\right)
$$

\footnotetext{
12 This makes the corresponding remuneration of deposits in domestic and foreign currency equivalent.
} 
where $C d>0$ only if $\check{C}>G x+D x$ and

$$
\check{C}=D d+C x \quad \text { if } \delta_{1}>\sigma_{0} c /\left(1+r_{1} x+\sigma_{1} p\right),
$$

where $C x>0$ only if $\check{C}>D d$.

Abandoning now the assumption that banks keep their positions balanced, a long history of continuous exchange rate depreciation may have resulted in long foreign exchange positions in bank balance sheets and sizable dollarization of deposits:

$$
D x+G x<C x+S x \text {, }
$$

if $\delta<\sigma c /(1+r x+\sigma p)$ and $\operatorname{ABS}(\delta-\sigma c /(1+r x+\sigma p)\}<\varsigma,{ }^{13}$ banks' long positions and dollarization of deposits would not be modified. However, as $S x$ can never be more profitable than $C x$ (both are affected by $\delta$ ), $C x$ could expand quickly if $G_{x}$ is underutilized. Therefore, if there are sizable deposits in foreign currency, banks hold a long foreign exchange position, foreign borrowing is underutilized, ${ }^{14}$ and exchange rate depreciation remains below expectations implicit in interest rate differentials, banks can accommodate an exchange-rateinduced higher demand for foreign currency loans such that:

$$
\Delta(C x / \check{C})>0
$$

Borrowers undertake exchange rate risk (and banks assume the corresponding credit risk) in the expectation that this will not materialize during the maturity of the loan. To analyze a scenario in which both risks materialize, we need to incorporate the role of default.

\section{B. Expected and Actual Default}

In principle, actual default rates must compensate for the default risk premium (consistent with zero profits), such that: ${ }^{15}$

$$
\Theta_{1}=\sigma_{0} f /\left(r_{1} x+\sigma_{1} p+\sigma_{0} c+\sigma_{0} f\right) \quad \text { (for domestic currency), }
$$

and:

$$
\Theta_{1}=\sigma_{0} f /\left(r_{l} x+\sigma_{1} p+\delta_{1}\left(1+r_{1} x+\sigma_{1} p\right)+\sigma_{0} f\right) \quad \text { (for foreign currency loans). }{ }^{16}(11 \mathrm{a})
$$

${ }^{13}$ For example, because of fear of floating by monetary authorities.

${ }^{14}$ Or alternatively, access to foreign borrowing increases.

15 This would make the interest rate on deposits and loans equivalent for both currencies (zero profits). 
Introducing unhedged borrowing would imply that the exchange rate may affect default, such that:

$$
\Theta=f(\delta)
$$

As the assumption of perfect foresight is abandoned, default on domestic currency loans would depend on the expected exchange rate depreciation:

$$
\Theta x=f(\delta)
$$

and

$$
\Theta d=f(\sigma c)
$$

The impact of a surprise exchange rate depreciation that does not reflect on $\sigma c$ would result from the following sequence of events:

- In period 0 , if there is an environment in which borrowers expect $\mathrm{E}\left(\delta_{1}\right)<\sigma_{0} c /(1+$ $\left.r_{0} x+\sigma_{0} p\right)$ and $\mathrm{ABS}\left(\mathrm{E}\left(\delta_{1}\right)-\sigma_{0} c /\left(1+r_{0} x+\sigma_{0} p\right)\right\}<\varsigma$, a higher expectation of default for domestic currency loans would be consistent with an increase in $C x{ }^{17}$

- In period 1 , if $\delta_{1}>\sigma_{0} c /\left(1+r_{1} x+\sigma_{1} p\right)>\mathrm{E}\left(\delta_{1}\right)$, ex-post default in foreign currency loans would be higher than in domestic currency, as exchange rate depreciation is larger than the one that would make domestic and foreign currency loan interest rates equivalent.

If $G x$ also depends in turn on the observed rate of default, then we have:

$$
G x=h(\Theta x)
$$

Thus, a surprise depreciation would have the following effect: (i) increase the relative size of the banks' foreign exchange long position (from 8); (ii) increase the share of foreign currency deposits (from 10); and (iii) decrease $G x$. Banks would prefer to increase $S x$ to protect from currency risk rather than increase $C d$ to substitute for the reduction in $C x$. This would in turn lead to a decrease in the supply of credit. Prudential measures should aim at preventing this possibility of simultaneous distress of banks and borrowers that may result in a vicious circle

\footnotetext{
${ }^{16}$ Foreign banks make profits because default rates are lower than those required for breaking even, as long as they are immune to the country risk premium.

17 This is consistent with the perception that foreign currency loans are granted to "better customers," an argument commonly used by banks to justify unhedged lending. What this formulation suggests is that the "good customer" element may well be in part the endogenous result of lower effective interest rates.
} 
of a reduction of assets below liabilities (negative capital) followed by continuous reductions in the banks' credit supply.

It should be noted that even if the surprise exchange rate depreciation affected $\sigma c$, the behavior of depositors and foreign and domestic banks would be the same. The costs of default would be larger and the distress in banks and borrowers would be more severe. This may add a moral hazard component in borrowing in foreign currency, as some borrowers know that a scenario of a sizable exchange rate depreciation would lead them into default for any currency denomination of their loans, ${ }^{18}$ while they may benefit from any lagged adjustment of $\sigma c$.

\section{Impact of STG Provisioning}

The imposition of a STG provision on unhedged foreign currency loans in this framework will increase the cost of lending in foreign currency, and will also increase the equity component on the liability side of the bank's balance sheet (in this case, from zero to a positive number). ${ }^{19}$ For illustration purposes, this reserve is included with a negative sign in the asset equation. If the provision is set at $\rho$, we would have:

$$
\begin{aligned}
& \text { Total liabilities }=D x+D d+G x \text { and } \\
& \text { Total assets }=C d+C x(1-\rho)+S x .
\end{aligned}
$$

If banks absorb all the cost of provisioning, the cost of liabilities remains the same, but the yield on foreign currency lending is reduced by $\rho$ :

$$
r_{0} c_{x}=r_{0} x+\sigma_{0} p+\sigma_{0} f-\rho
$$

In order to make lending in domestic and foreign currency yield-indifferent, and considering that $\delta_{1}$ is unknown, the STG provisioning ratio could be set at:

$$
\rho=\sigma_{0} c /\left(1+r_{l} x+\sigma_{l} p\right)-\delta_{0}
$$

Thus, the STG provision would be equivalent to the differential cost of borrowing in domestic and foreign currency. In practice, the STG provision could be proportional to this differential (i.e., $\rho$ would be multiplied by a coefficient between zero and one). The imposition of $\rho$ makes foreign exchange long positions costly for banks. Adding $\rho$ to transaction costs, one would arrive at:

18 This idea was suggested by Paul Kupiec.

19 This would be equivalent to stating that corresponding reserves would be in addition to the applicable standard capital requirements, creating supplemental regulatory capital buffers during the period when the risk has not materialized (see Kupiec 2002). 
$\Delta\{(C x(1-\rho)+S x) /(D x+G x)\}=f\left\{\left(\delta_{1}-\rho[C x /(D x+G x)]-\sigma_{0} c /\left(1+r_{1} x+\sigma_{1} p\right)\right\}\right.$ if $\operatorname{ABS}\left(\delta_{1}-\rho[C x /(D x+G x)]-\sigma_{0} c /\left(1+r_{1} x+\sigma_{1} p\right)\right\}>\varsigma$ , and zero otherwise.

Therefore, there are at least four channels through which $\rho$ would affect bank behavior:

- $\quad$ Only increases in hedged $C x$ will result in net changes in the foreign exchange position of banks.

- $\quad$ The country risk premium $\sigma p$ is not always compensated by lending in foreign currency. This would depend on the difference between $\sigma p-\rho$.

- $\quad$ The larger the discrepancy between the implicit currency risk premium and actual depreciation ( $\sigma c$ and $\delta_{0}$ ), the more costly for banks is the imposition of $\rho$.

- $\quad$ The imposition of $\rho$ creates a bias toward shorter foreign exchange positions, as required exchange rate depreciation leading to longer foreign exchange positions would be higher with $\rho$.

Therefore, banks would not only reduce their exposure to $C x$, but would have less incentive to hold a long foreign exchange position and would have more incentive to keep foreign exchange assets in the safest alternative. In addition, for the same value and composition of liabilities, the additional implicit retained earnings would need to be compensated by larger assets through a combination of higher $C d$ and $S x$.

This proposal has the following advantages:

- $\quad$ Banks would be specifically covering exchange-rate-induced credit risk more effectively than by holding a long foreign exchange position with an embedded credit risk component of uncertain magnitude.

- The costs of provisioning would evolve over time to adjust to the relative exposure to exchange-rate-induced credit risk.

- Such a situation creates incentives to keep a larger share of foreign exchange assets in a risk-free alternative.

Note that most of the effects would vanish if banks transfer the cost of higher provisioning to the consumer (which may be the case in relatively closed financial systems). However, this would imply that borrowers would have less incentives to unhedged borrowing in foreign currency since the cost of borrowing would be higher. Moreover, it would still be true that only increases in hedged $C x$ will result in net changes in the foreign exchange position of banks, which would encourage a larger share of foreign exchange assets invested in a riskfree alternative. 


\section{Implementation Issues}

It is generally expected that this measure would induce banks to be more careful when granting foreign exchange loans, since risks are internalized. In turn, this means that borrowers would have access to a shorter domestic supply of credit. If offshore alternatives are available, this could lead to some disintermediation of loans and deposits. Two issues are worth mentioning: (i) offshore banks could also become aware of the risks if information on corresponding provisioning is publicly available and (ii) provisioning may entail a signaling effect that could help bank customers make more informed decisions. They would be made more aware of the potential risks that off-shore banks may be taking when accepting foreign exchange deposits to onlend them to unhedged borrowers in jurisdictions where deposit protection may not apply.

It is possible that banks may resort to discouraging foreign currency deposits in the face of higher costs, through extending lower interest rates and/or commissions and higher minimum deposit requirements. In heavily dollarized economies, more susceptible to quick disintermediation, foreign currency deposits could be transferred abroad within a short period. To minimize this risk, it would be more important in these countries that overall confidence in the financial system is enhanced by improving banks' soundness and strengthening financial supervision.

The definition of unhedged borrowing is a practical problem to be addressed, which is beyond the scope of this paper. Are distributors of foreign goods in the domestic market hedged to the extent that they quote dollar prices? Are providers to commodity-exporter industries hedged to the extent that the source of cash flow of their customers is in foreign currency? Generally, this all would depend on the magnitude of the exchange-rate passthrough (the higher the pass-through, the more linked are domestic prices in dollars to foreign prices). Additional guidelines are necessary to identify gray areas before making this proposal operational.

There may be a problem related to tax and accounting standards, which may justify adaptations of this proposal (e.g., turning the provisioning into a liquidity requirement, as in Kupiec, 2002). This would depend on the particular conformity to international standards by financial institutions in a specific country. However, this could well be a transitory problem based on recent discussions in supervisory and accounting bodies. Depending on the profitability of banks and the status of tax and accounting standards, it may be useful in some jurisdictions to use the provision to set aside reserves without affecting profit-and-loss statements. $^{20}$

Compliance by foreign banks could be complicated depending on if they are bank offices operating domestically, branches, or if they operate directly from abroad. Care must be taken to avoid differences in treatment in the form of regulatory arbitrage (the same foreign bank subject to different rules when operating in the domestic market or from abroad). Anecdotal

${ }^{20}$ This idea was provided by Luis Cortavarria. 
evidence shows that conservative banks may be experiencing the opposite problem in the current circumstances: Domestic banks lending in foreign currency to unhedged borrowers that foreign banks are not willing to lend to without adequate coverage. Initial circumstances would determine how this proposal would be implemented in these cases.

In the implementation of provisioning, banks with more sophisticated risk management systems should be allowed to incorporate more ad hoc criteria for risk management of their loan portfolio. ${ }^{21}$ The STG provisioning would only apply if banks fail to prove to the supervisory authorities that this is the case. In general, none of the proposed measures excludes the combined use of one or more of the other alternatives, and they all may constitute part of a prudential package to be considered by supervisory authorities to be adapted to the particular circumstances of each country.

\section{Conclusions}

Bank borrowers' currency mismatches are sources of damaging "balance sheet" effects at times of sudden exchange rate depreciation, often when financial crises occur. However, addressing this source of risk is difficult because of several factors - the risk of arresting financial development, the absence of agreed-upon adaptations to prudential norms, and the absence of specific regulations in more developed financial markets that could be used as references.

The nature of risks entailed in unhedged foreign currency borrowing results from a unique incentive framework. Borrowers expect that the exchange rate risk will not materialize within the maturity of their loans; the central bank may be willing to provide an implicit "exchange rate insurance"; and banks can allocate liabilities to the highest-yield alternative while keeping their foreign exchange position balanced or long. Alternative measures should lead to the internalization of concomitant risks by banks and their borrowers, while minimizing moral hazard risks. In practice, countries have resorted to exchange controls, which are generally undesirable and inconsistent with financial globalization. However, restricting foreign currency lending only to hedged borrowers may be justified in cases of moderate dollarization.

What supervisory tools are available for countries already facing a significant problem of bank borrowers' currency mismatches? Recent proposals to improve international accounting standards and to modify the guidelines for loan classification and provisioning may provide an opportunity to incorporate consistent modifications. This paper proposes one practical approach, namely setting loan-loss provisions proportional to the historical difference between the banks' domestic and foreign currency lending rates. Such a measure would not only make unhedged foreign currency lending more expensive, but would discourage banks from keeping long positions built up through assets affected by exchange-rate-induced credit

${ }^{21}$ Recently, Peru explicitly incorporated unhedged foreign currency borrowing as a criterion for loan classification. 
risk. It would also encourage banks to allocate foreign currency assets to the safest alternatives.

More generally, the choice of the most appropriate tools would depend on the degree of dollarization, the possibility of a quick move toward to offshore operations, the quality of banking supervision, and the familiarity of banking institutions with internationally accepted accounting standards. It should be kept in mind that less stringent measures may be satisfactory if credit risk management is generally conducted prudently by banks and firms. 


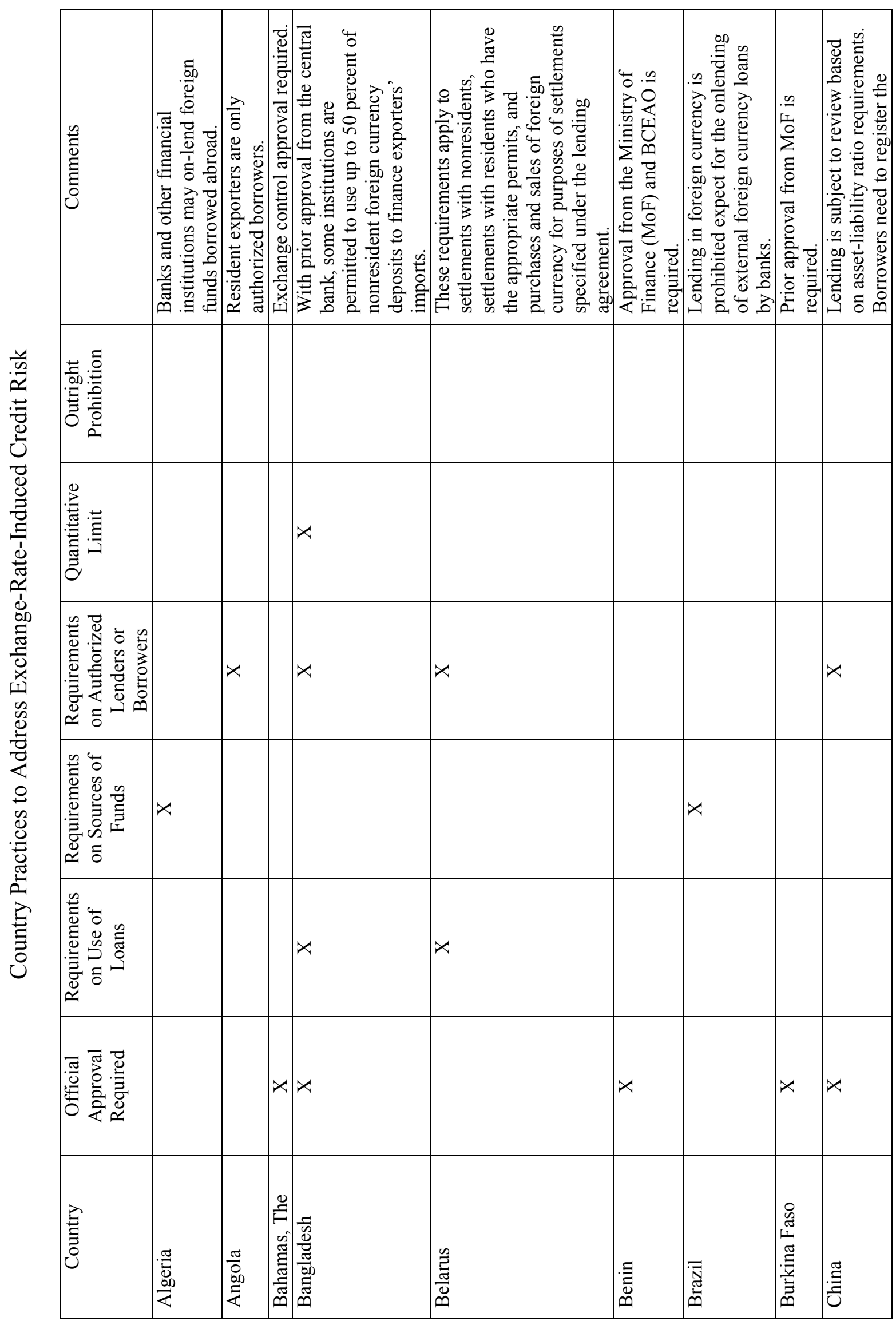




\begin{tabular}{|c|c|c|c|c|c|c|c|c|c|c|c|}
\hline 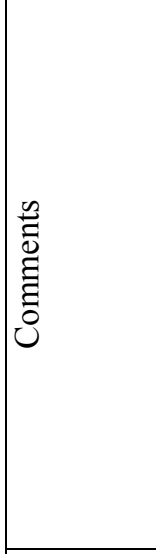 & 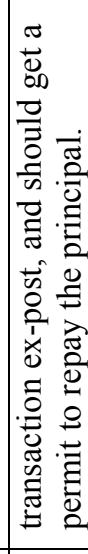 & 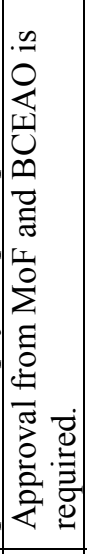 & 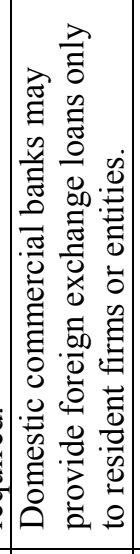 & 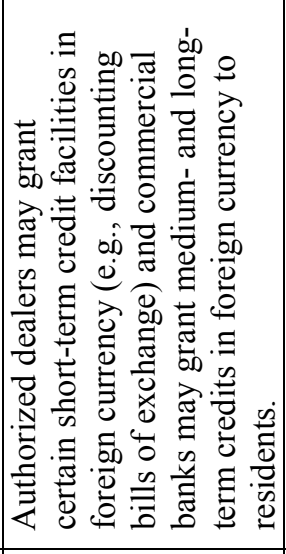 & 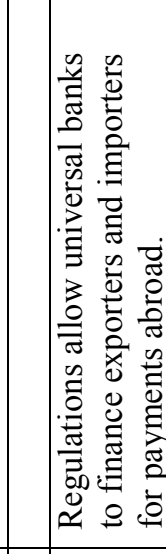 & 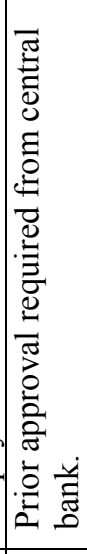 & 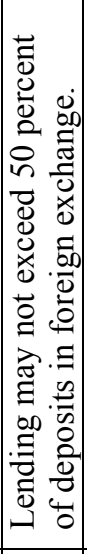 & 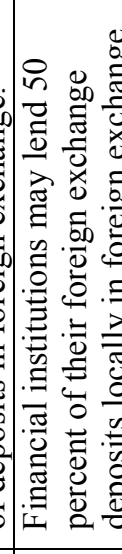 & 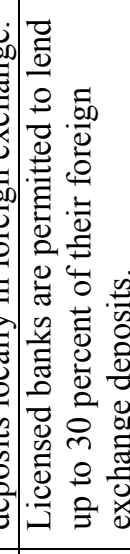 & 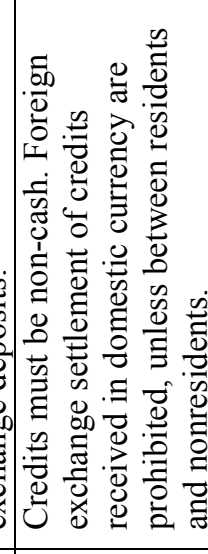 & \\
\hline 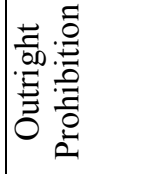 & & & & & $|x|$ & & & & & & $x$ \\
\hline 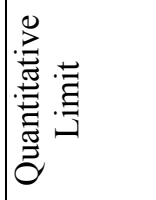 & & & & & & & $x$ & $\rtimes$ & $x$ & & \\
\hline 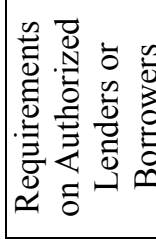 & & & $x$ & $x$ & $x$ & & & & & $x$ & \\
\hline 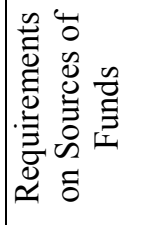 & & & & & & & & & & & \\
\hline 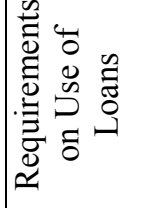 & & & & & $\rtimes$ & & & & & $\rtimes$ & \\
\hline 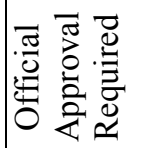 & & $x$ & & $x$ & & $x$ & & & & & \\
\hline 言 & & $\mid \begin{array}{l}0 \\
.0 \\
0 \\
0 \\
0 \\
0 \\
0 \\
0 \\
0\end{array}$ & 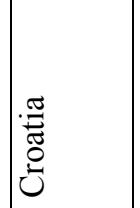 & 憵 & : & 洋 & 考 & 焉 & 胥 & 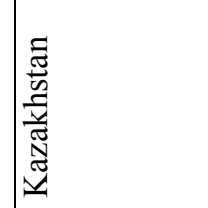 & \\
\hline
\end{tabular}




\begin{tabular}{|c|c|c|c|c|c|c|c|c|c|c|c|}
\hline 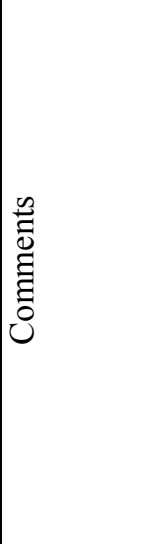 & 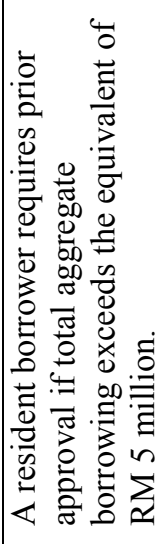 & 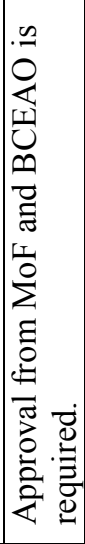 & & 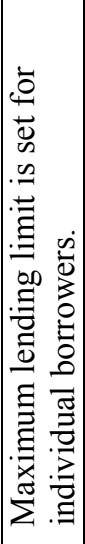 & 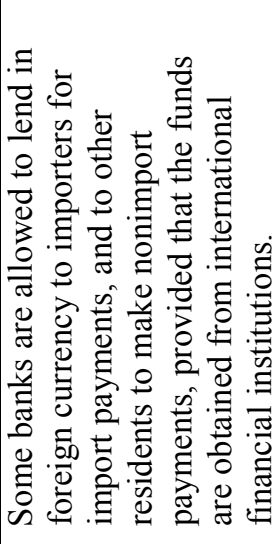 & 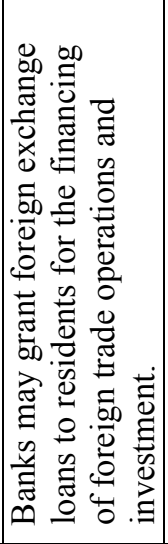 & & 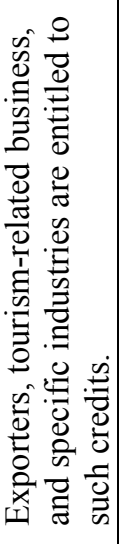 & 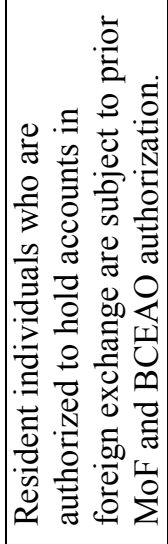 & 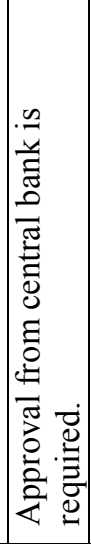 & 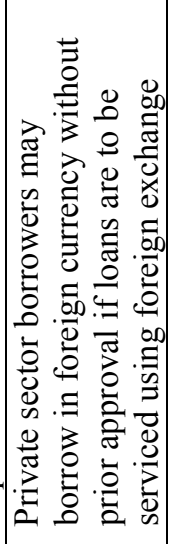 \\
\hline 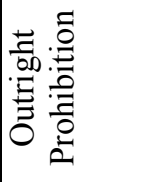 & & & & & & & $x$ & & & & \\
\hline 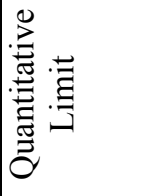 & $x$ & & & $x$ & & & & & & & \\
\hline 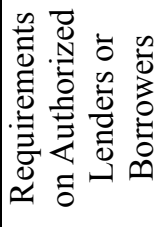 & $x$ & & $x$ & & $x$ & & & & $x$ & & \\
\hline 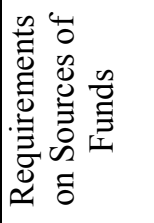 & & & & & $x$ & & & & & & \\
\hline 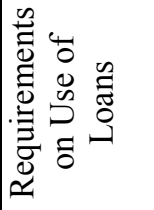 & & & & & $x$ & $x$ & & $x$ & & & $x$ \\
\hline 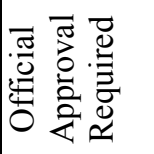 & $x$ & $x$ & & & & & & & $x$ & $x$ & $x$ \\
\hline 总 & $\mid \begin{array}{l}\frac{\pi}{\pi} \\
\frac{\pi}{\pi} \\
\frac{\pi}{\pi} \\
\sum\end{array}$ & $\sum^{\bar{\pi}}$ & : & 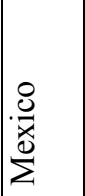 & $\frac{\pi}{0}$ & $\begin{array}{l}0 \\
0 \\
0 \\
0 \\
0 \\
\Sigma \\
\Sigma\end{array}$ & 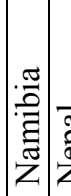 & $\begin{array}{l}\bar{\pi} \\
\frac{\tilde{0}}{0} \\
\bar{z}\end{array}$ & $\frac{\bar{D}}{\Delta, 0}$ & 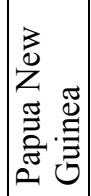 & 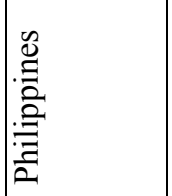 \\
\hline
\end{tabular}




\begin{tabular}{|c|c|c|c|c|c|c|c|c|}
\hline 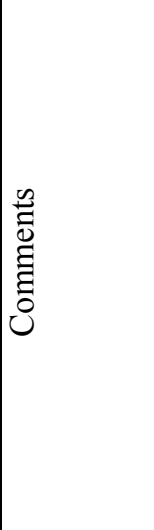 & 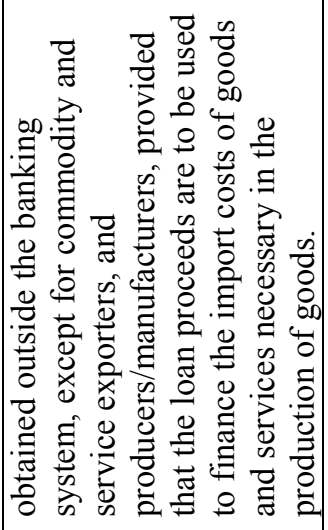 & & 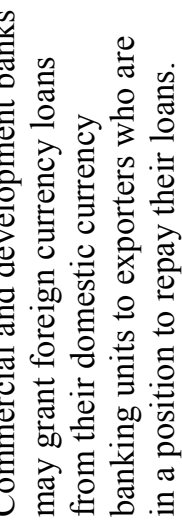 & 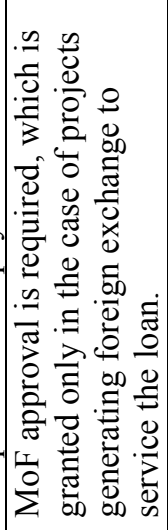 & 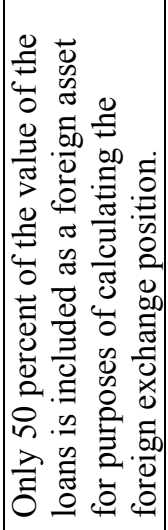 & 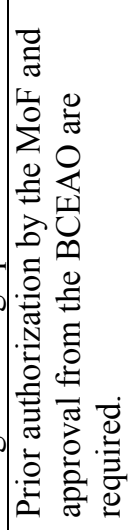 & 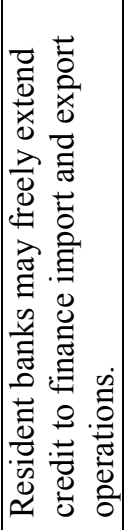 & 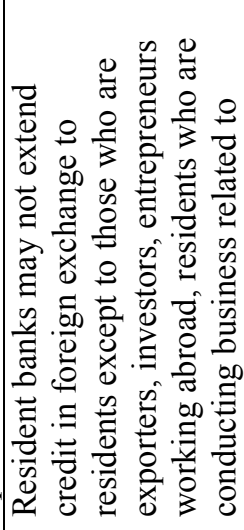 \\
\hline 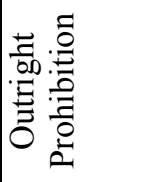 & & & & & & & & \\
\hline 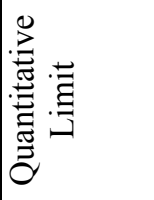 & & & & & $x$ & & & \\
\hline 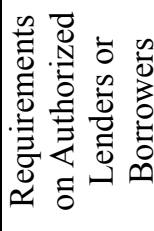 & & $x \mid x$ & & & & & & $x$ \\
\hline 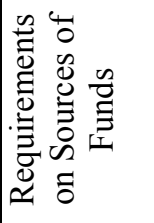 & & & & & & & & \\
\hline 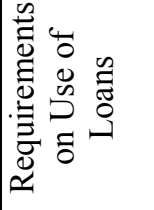 & & & & $x$ & & & $x$ & $x$ \\
\hline 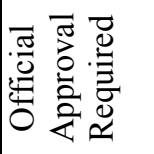 & & & & $x$ & & $x$ & & $x$ \\
\hline 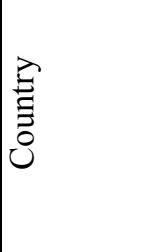 & & 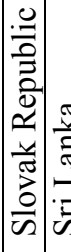 & & 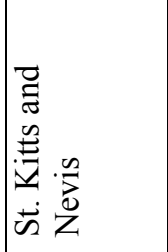 & 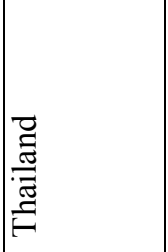 & 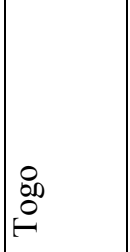 & 駡 & 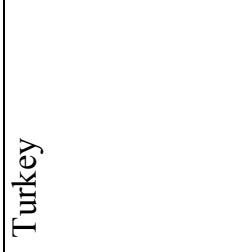 \\
\hline
\end{tabular}




\begin{tabular}{|c|c|c|c|c|}
\hline 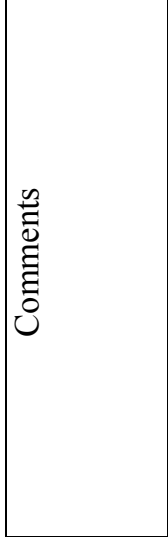 & 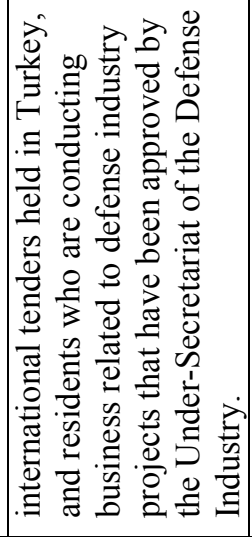 & 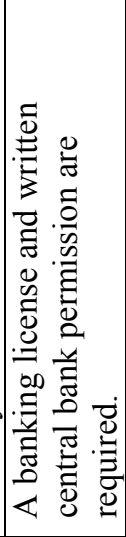 & 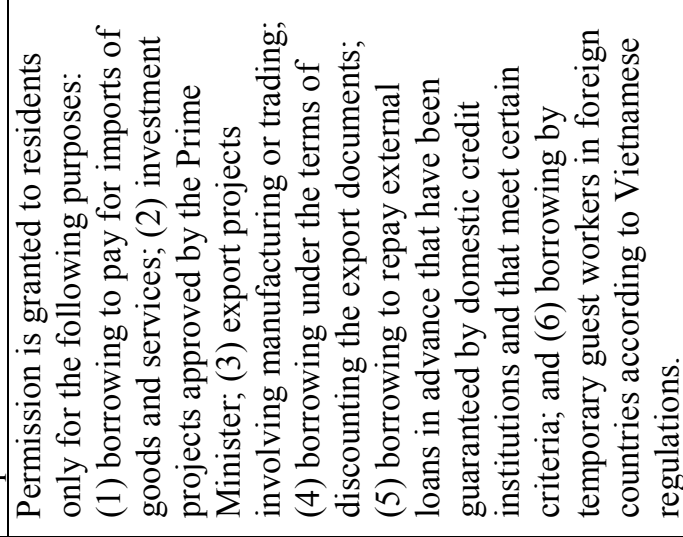 & 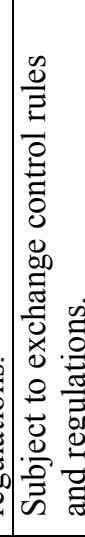 \\
\hline 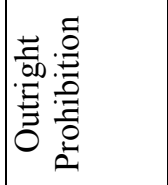 & & & & \\
\hline 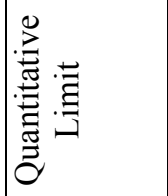 & & & & \\
\hline 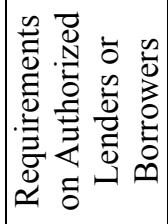 & & $x$ & & \\
\hline 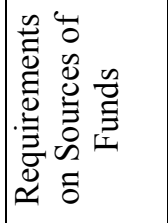 & & & & \\
\hline 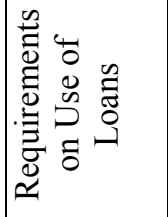 & & & $x$ & \\
\hline 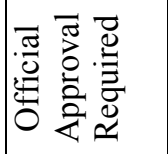 & & $x$ & & $x$ \\
\hline $\begin{array}{l}\text { 音 } \\
\text { 己 }\end{array}$ & & 竘 & 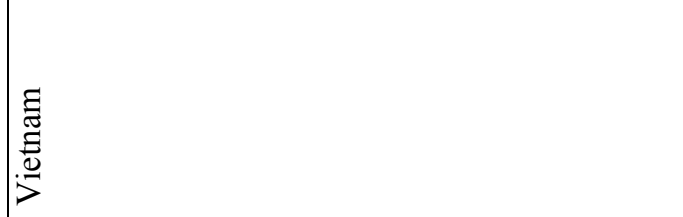 & 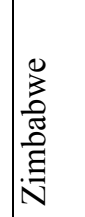 \\
\hline
\end{tabular}

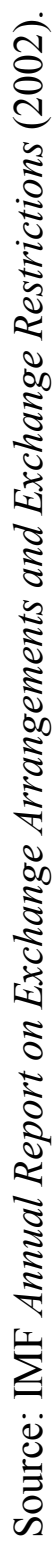




\section{References}

Baliño, Tomás J.T., Adam Bennet, and Eduardo Borensztein, 1999, Monetary Policy in Dollarized Economies, IMF Occasional Paper N ${ }^{\circ} 171$ (Washington: International Monetary Fund).

Bank for International Settlements, 1998, Amendment to the Capital Accord to Incorporate Market Risks (Basel).

Bank for International Settlements, 2002, Sound Practices for Loan Accounting (Basel).

Barajas, Adolfo and R. Armando Morales, 2003, "Dollarization of Liabilities: Beyond the Usual Suspects,” IMF Working Paper 03/11 (Washington: International Monetary Fund).

Borio, Claudio and P. Lowe, 2001 "To Provision or Not to Provision," BIS Quarterly Review, September.

Burnside, Craig, Martin Eichenbaum, and Sergio Rebelo, 1999, "Hedging and Financial Fragility in Fixed Exchange Rate Regimes," National Bureau of Economic Research Working Paper No 7143 (Cambridge, Massachusetts: National Bureau of Economic Research).

Calvo, Guillermo and Carmen Reinhart, 2000, "Fear of Floating," National Bureau of Economic Research Working Paper No 7993 (Cambridge, Massachusetts: National Bureau of Economic Research).

Caprio, Gerard and Daniela Klingebiel, 1996, "Bank Insolvencies: Cross-Country Experience," World Bank Policy Research Working Paper No 1620 (Washington: the World Bank).

Delgado, Fernando, Daniel Kanda, Greta Mitchell Casselle, and R. Armando Morales, 2002, "Domestic Lending in Foreign Currency," in Building Strong Banks Through Surveillance and Resolution, ed. by C. Enoch, D. Marston and M. Taylor (Washington: International Monetary Fund).

Dooley, Michael, 1997, “A Model of Crises in Emerging Markets,” National Bureau of Economic Research Working Paper No 6300, December Cambridge, Massachusetts: National Bureau of Economic Research).

Financial Stability Forum, 2000, Report of the Working Group on Capital Flows (Singapore: Financial Stability Forum). 
Goldstein, Morris and Phillip Turner, 1996, "Banking Crises in Emerging Economies: Origins and Policy Options,” BIS Economic Papers No 46 (Basel: Bank for International Settlements).

Honohan, Patrick and A. Shi, 2002, "Deposit Dollarization and the Financial Sector in Emerging Economies" (unpublished, Washington: the World Bank).

International Accounting Standards Committee Foundation, 2002a, Improvements to IAS 39, Financial Instruments: Recognition and Measurement (unpublished, London: International Accounting Standards Committee).

— 2002b, Proposed Improvements to International Accounting Standard IAS 21 (unpublished, London: International Accounting Standards Committee).

International Monetary Fund, 2002, Annual Report on Exchange Arrangements and Exchange Restrictions (Washington: International Monetary Fund).

Kupiec, Paul, 2002, Prudential Bank Regulation, Credit Growth and Business Cycle (unpublished, Washington: International Monetary Fund).

World Bank, 2002, Loan Classification and Provisioning Among Members of the Basel Core Principle Liaison Group (unpublished, Washington: the World Bank). 